\title{
Optical Control of Lipid Rafts with
}

\section{Photoswitchable Ceramides}

\author{
James Allen Frank ${ }^{1}$, Henri G. Franquelim ${ }^{2}$, Petra Schwille ${ }^{{ }^{2}}$, Dirk Trauner ${ }^{\star 1}$
}

\begin{abstract}
${ }^{1}$ Department of Chemistry and Center for Integrated Protein Science, Ludwig Maximilians University Munich, Butenandtstraße 5-13, 81377 Munich, Germany. ${ }^{2}$ Department of Cellular and Molecular Biophysics, Max Planck Institute of Biochemistry, Am Klopferspitz 18, 82152 Martinsried, Germany.
\end{abstract}

\section{SUPPORTING INFORMATION}

\section{Table of Contents}

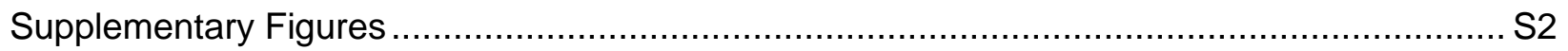

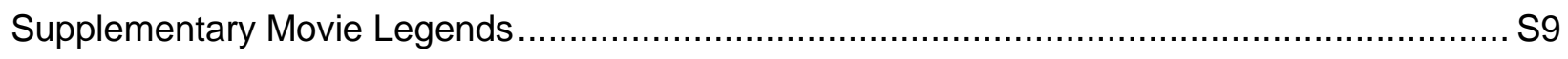

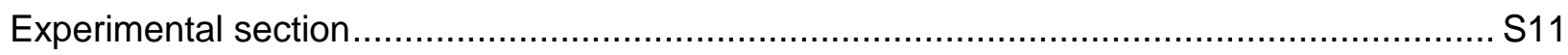

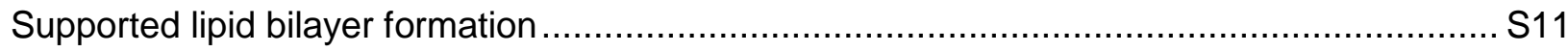

Combined Atomic Force and Confocal Microscopy ........................................................ S12

Compound Switching on Supported Lipid Bilayers ….................................................... S13

Compound Synthesis and Characterization ........................................................... 14

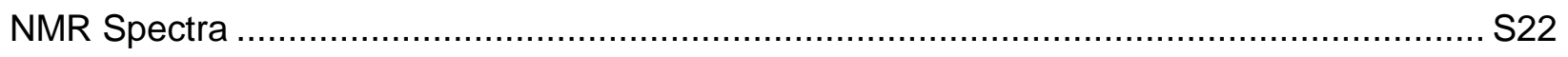

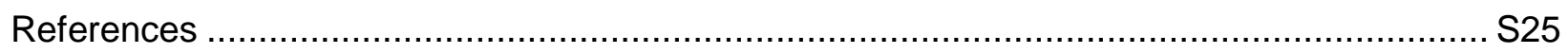




\section{Supplementary Figures}

a

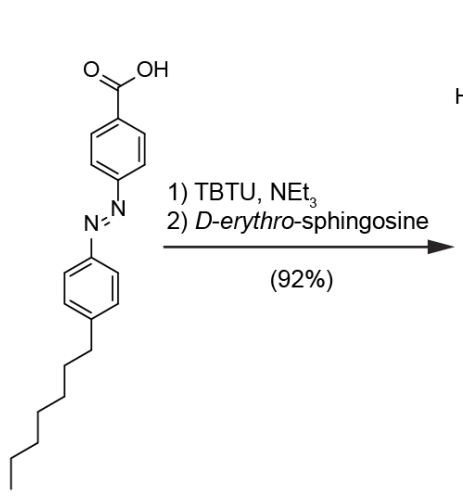

FAAzo-1

b

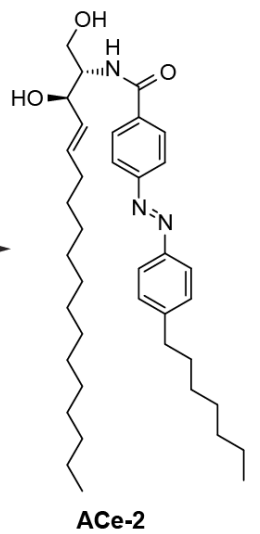

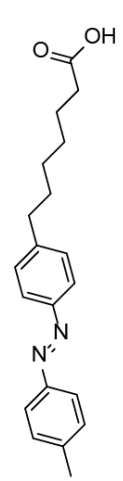

FAAzo-7

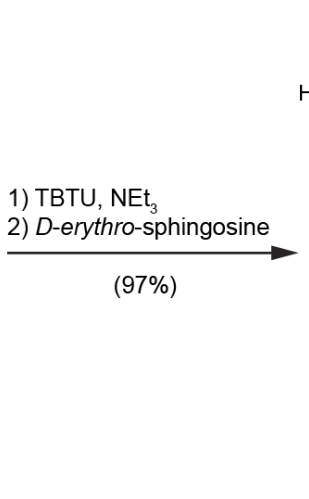

1) TBTU, NEt

2) D-erythro-sphingosine

$(97 \%)$

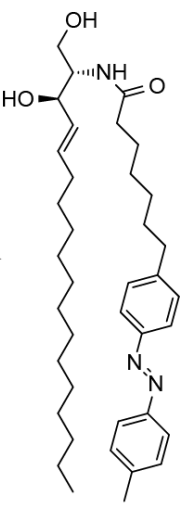

ACe-3

C

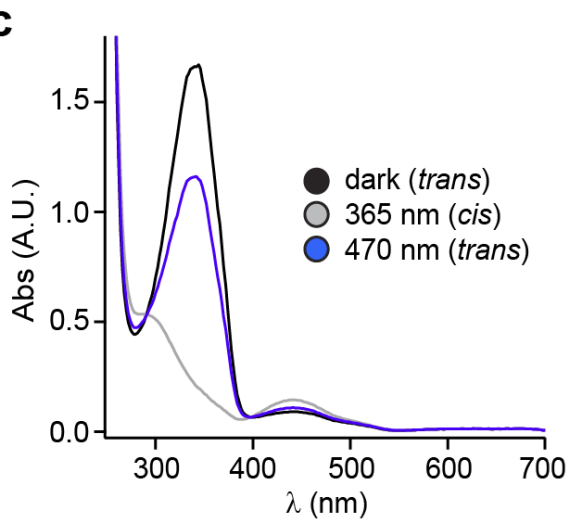

Figure S1. Synthesis and characterization of photoswitchable ceramides. The chemical syntheses of photoswitchable ceramides (a) ACe-2 and (b) ACe-3. Both compounds were prepared in high yield via an amide coupling between D-erythro-sphingosine and the photoswitchable fatty acids FAAzo-1 and FAAzo-7, respectively. (c) The UV-Vis spectra of dark- (black), UV- (gray) and blue-adapted (blue) ACe-1 (50 $\mu \mathrm{M}$ in DMSO). ACe-2 and ACe-3 possessed nearly identical spectral characteristics to $\mathbf{A C e}-\mathbf{1}$ in organic solution. 


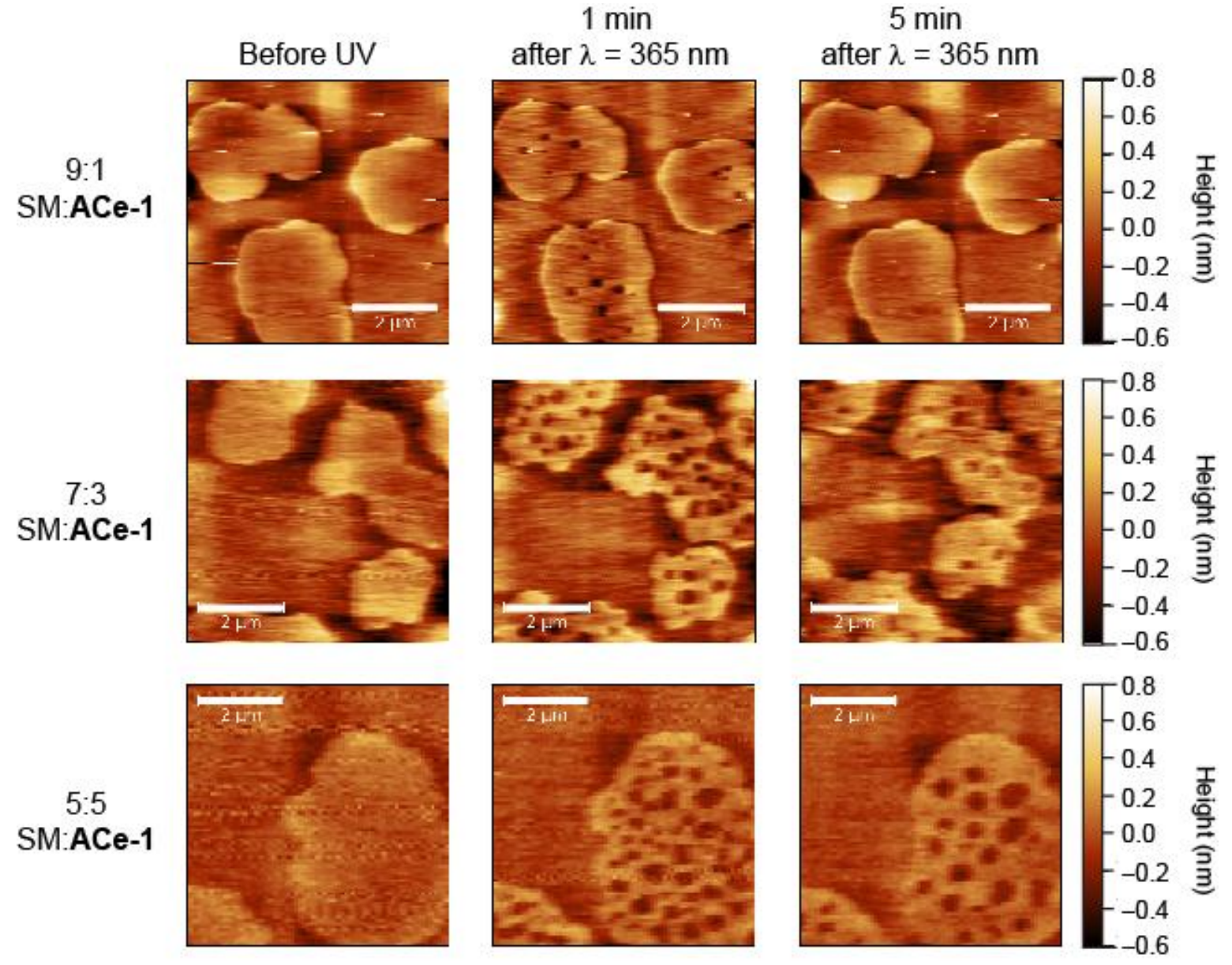

Figure S2. ACe-1 induces a concentration-dependent fluidification within the ordered $\left(L_{0}\right)$ domains on isomerization to cis. SLBs consisting of DOPC:cholesterol(Chol):sphingomyelin(SM):ACe-1 (10:6.7:X:Y mol ratio) were analyzed using contact mode atomic force microscopy (AFM). The SM:ACe-1 $X: Y$ ratio was varied between 9:1, 7:3 and 5:5. Immediately after irradiation with UV-A light $(\lambda=365 \mathrm{~nm})$, small $L_{d}$ lakes were observed within the $L_{o}$ domains. In the 7:3 and 5:5 SM:ACe-1 mixtures, those lakes fused together into larger $L_{d}$ domains and persisted more than 5 min after irradiation. In the 9:1 SM:ACe-1 mixture, the $L_{d}$ lakes had disappeared 5 min after irradiation. Scale bars $=2 \mu \mathrm{m}$. 
a

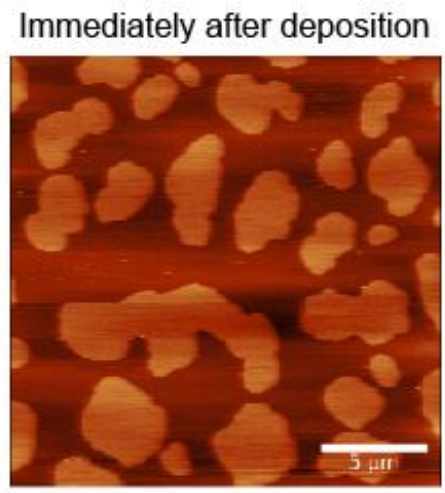

C

Immediately after deposition, after $\lambda=365 \mathrm{~nm}$

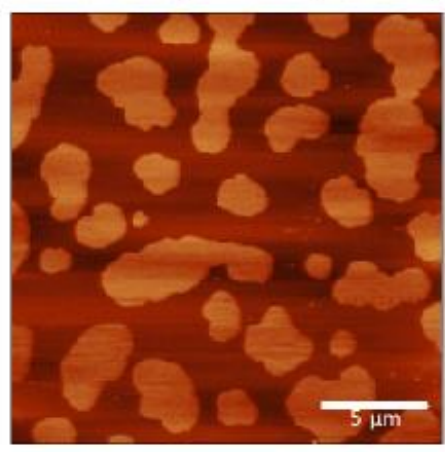

b

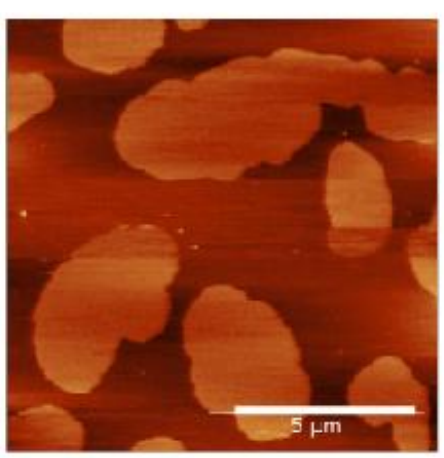

$>4 \mathrm{~h}$ after deposition

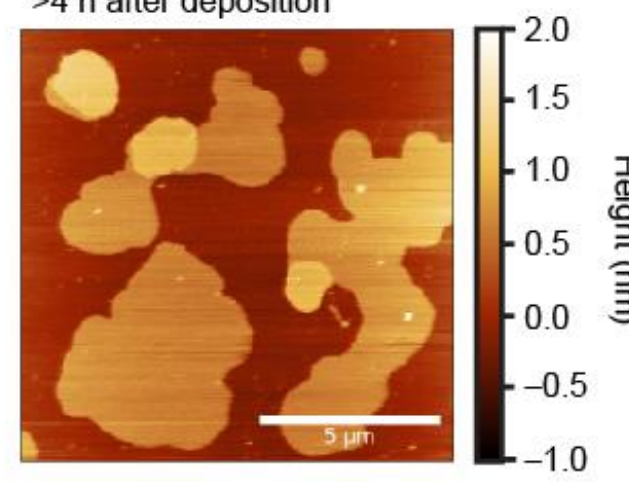

$>4 \mathrm{~h}$ after deposition, after $\lambda=365 \mathrm{~nm}$

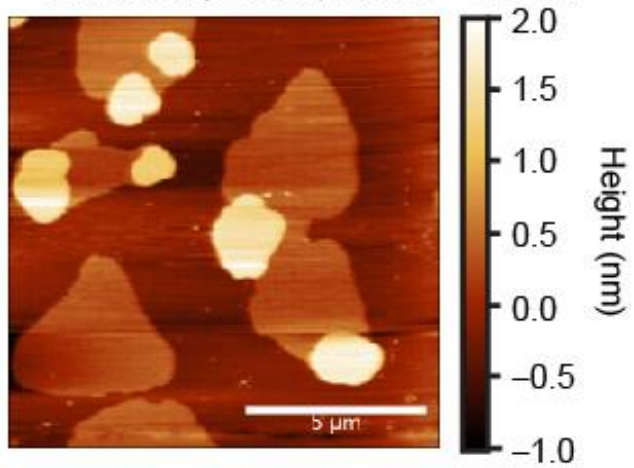

Figure S3. UV-A irradiation does not affect SLBs containing C18-Cer. Supported lipid bilayers (SLB) consisting of a of DOPC:Chol:SM:C18-Cer (10:6.7:7:3 mol ratio) were analyzed by contact mode AFM. Shown here is a representative SLB. (a) Immediately after deposition, a two-domain $L_{d}-L_{o}$ phaseseparated SLB was observed. (b) More than $4 \mathrm{~h}$ after deposition, a higher ceramide-rich gel-like phase appeared inside the $L_{o}$ domains. (c) Irradiation with UV-A light $(\lambda=365 \mathrm{~nm}, 10 \mathrm{~s})$ did not affect the structure of the SLB before or after the formation of the gel-like phase. Scale bars $=5 \mu \mathrm{m}$. 
a

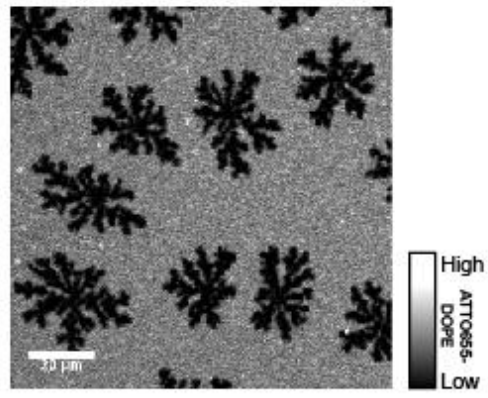

b

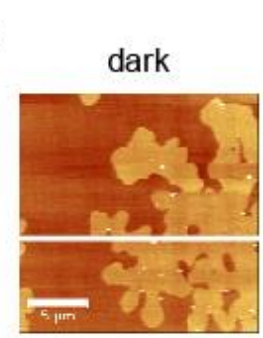

$\mathrm{S}_{\mathrm{o}} / \mathrm{L}_{\mathrm{d}}=0.72$
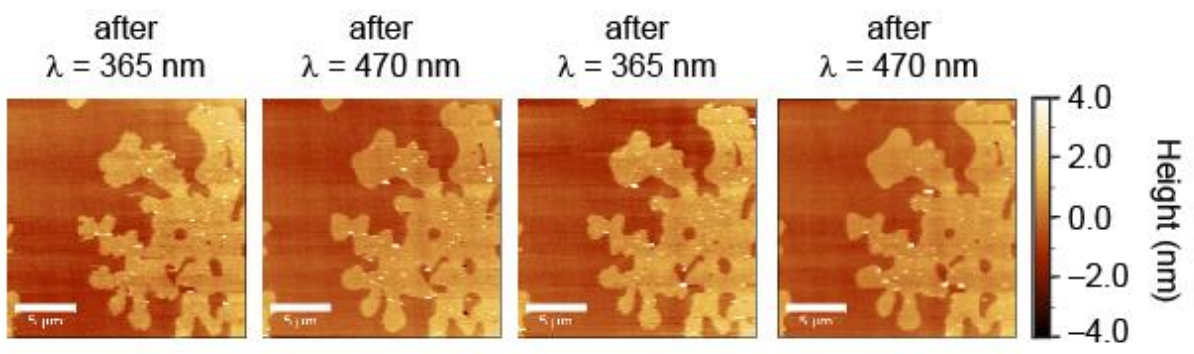

C
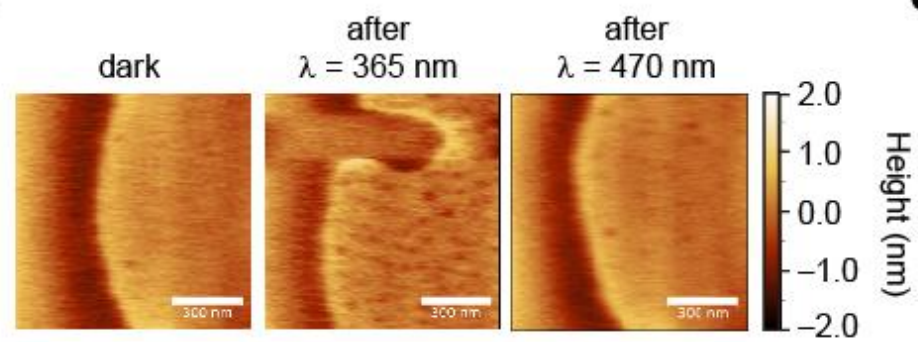

d

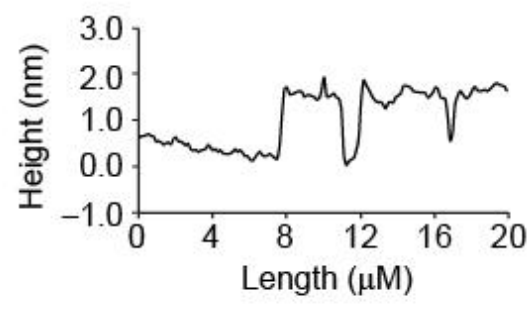

Figure S4. ACe-1 controls domain structure in a ternary lipid mixture. (a) Fluorescence microscopy revealed the presence of gel-like domains in a ternary lipid mixture containing 10:7:3 DOPC:SM:ACe-1 (with 0.1 mol\% ATTO655-DOPE) in the presence of trans-ACe-1. (b,c) Using AFM, we observed a fluidification of the gel-like domains on $\lambda=365 \mathrm{~nm}$ irradiation, as they shrunk slightly in size. Small holes were also observed within the domain on isomerization to cis. This effect could be reversed with $\lambda=470 \mathrm{~nm}$ irradiation. (d) The gel-like domains rested approximately 1.5-2.0 $\mathrm{nm}$ higher than the $\mathrm{L}_{d}$ domain, displayed as a profile sampled across the white line in b. Scale bars: $a=20 \mu \mathrm{m}, b=5 \mu \mathrm{m}$, $\mathrm{c}=300 \mathrm{~nm}$. 
a

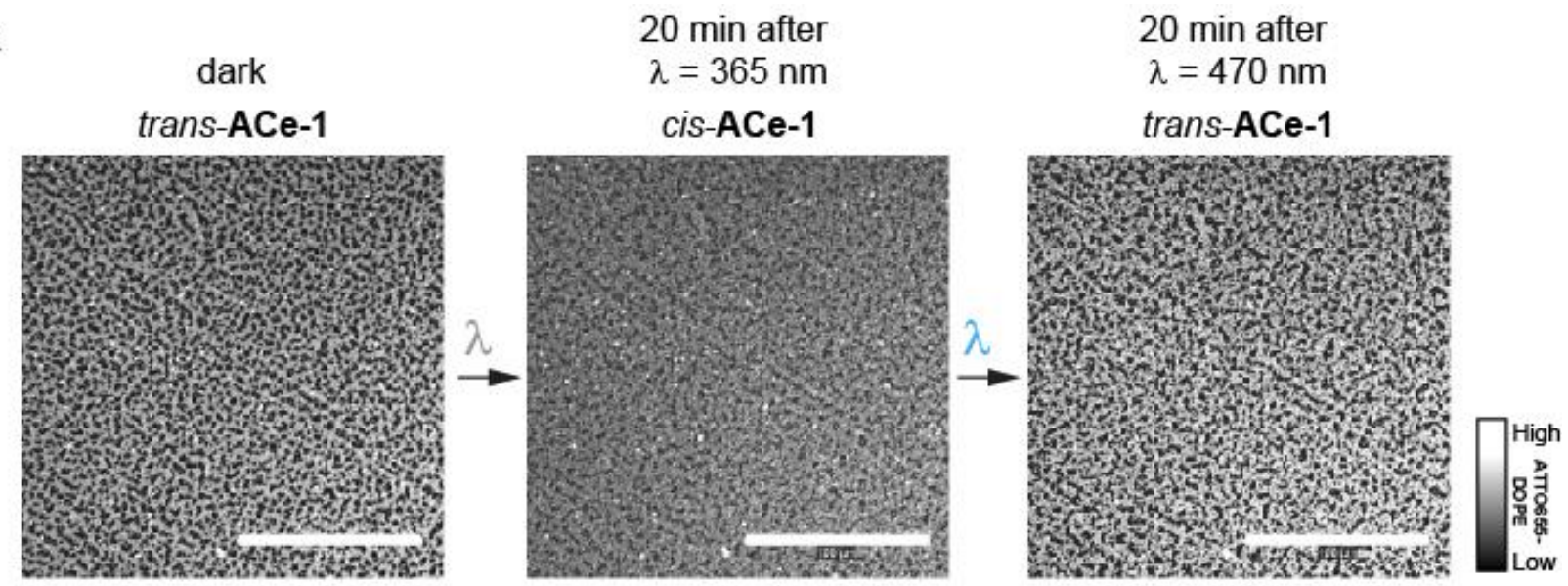

b

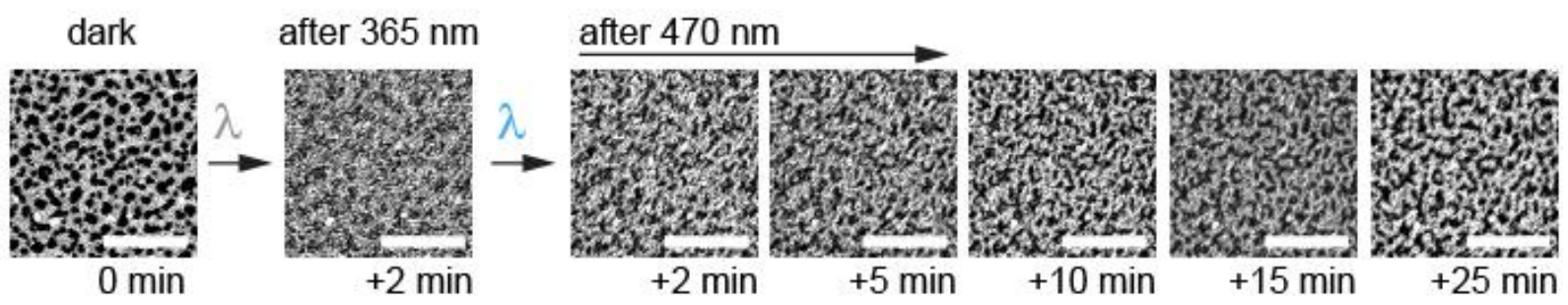

Figure S5. ACe-1 enables optical control of SLB structure. Confocal fluorescence microscopy of an SLB composed of a DOPC:Chol:SM:ACe-1 (10:6.7:5:5 mol ratio with 0.1\% ATTO655-DOPE) revealed $L_{\circ}$ domains (dark) within a fluid $L_{d}$ phase (bright). (a,b) On isomerization to cis-ACe-1 with $\lambda=365 \mathrm{~nm}$ irradiation (15 s) the dark $L_{\circ}$ domains shrunk and became less defined. On isomerization back to trans-ACe-1 with $\lambda=470 \mathrm{~nm}$ irradiation (15 s), the dark $L_{o}$ domains slowly took shape as the dye diffused back into the fluid domains. Scale bars: $a=100 \mu \mathrm{m}, \mathrm{b}=25 \mu \mathrm{m}$. 


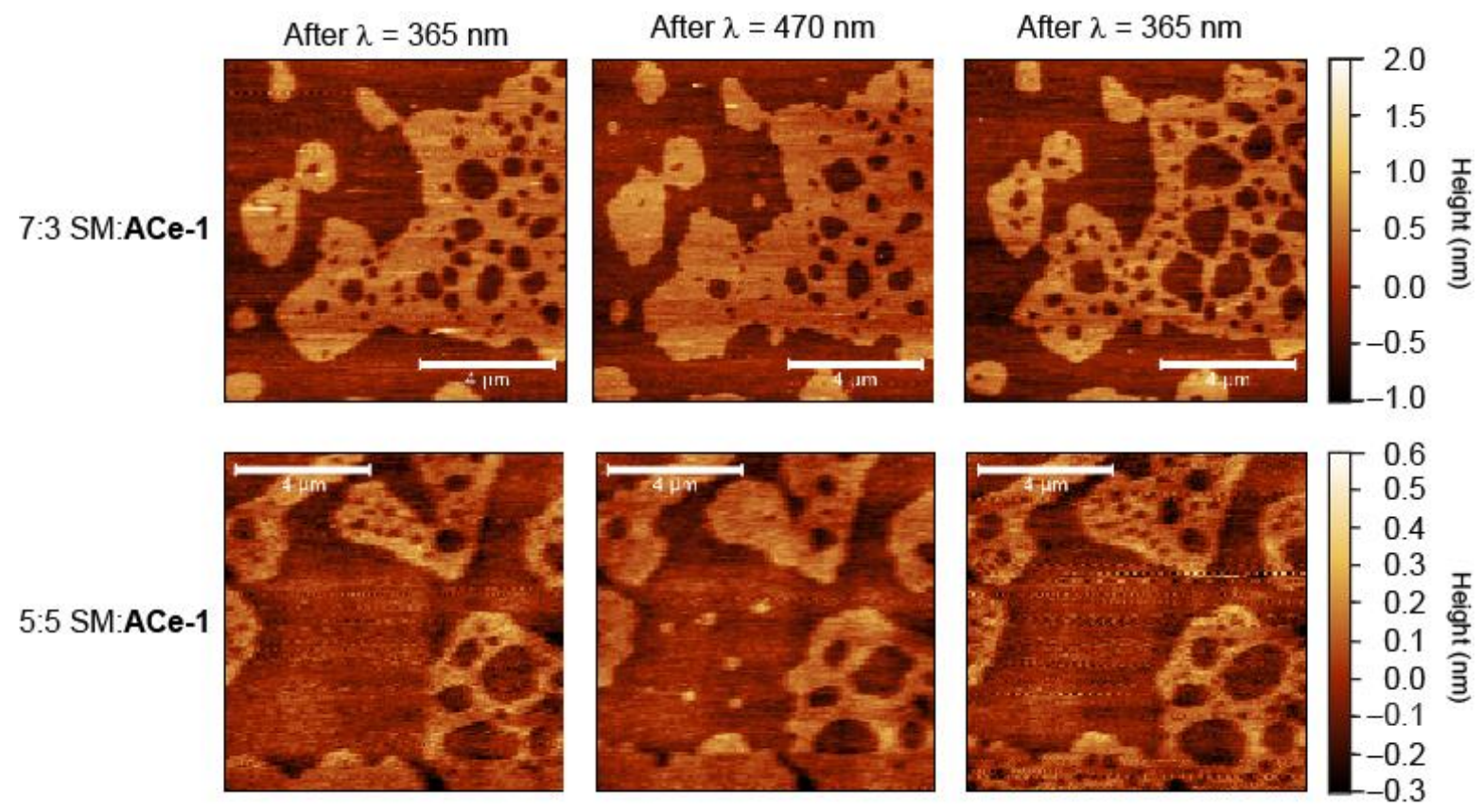

Figure S6. Ordered lipid domains are formed on isomerization from cis- to trans-ACe-1. SLBs consisting of DOPC:Chol:SM:ACe-1 (10:6.7:X:Y mol ratio) were analyzed using contact mode AFM. On isomerization to cis, $L_{d}$ lakes formed within the $L_{o}$ domains of the SLB. On blue irradiation and isomerization back to trans-ACe-1, $L_{o}$ islands were immediately observed within the $L_{d}$ phase. This effect could be repeated over multiple cycles. In the 5:5 SM:ACe-1 mixture, both holes and islands were more pronounced when compared to the 7:3 SM:ACe-1 SLB. Scale bars $=4 \mu \mathrm{m}$. 


\section{5:5 SM:ACe-2}

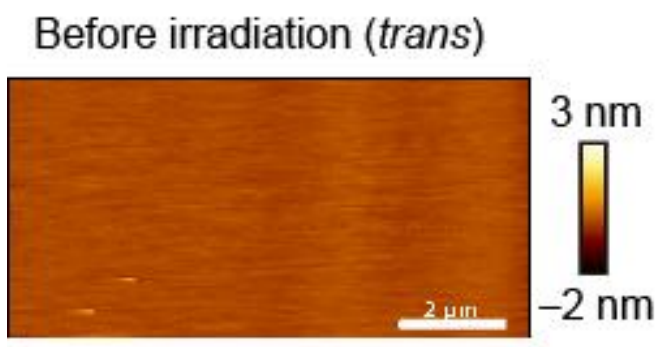

\section{Directly after}

$\lambda=365 \mathrm{~nm}$ (cis)
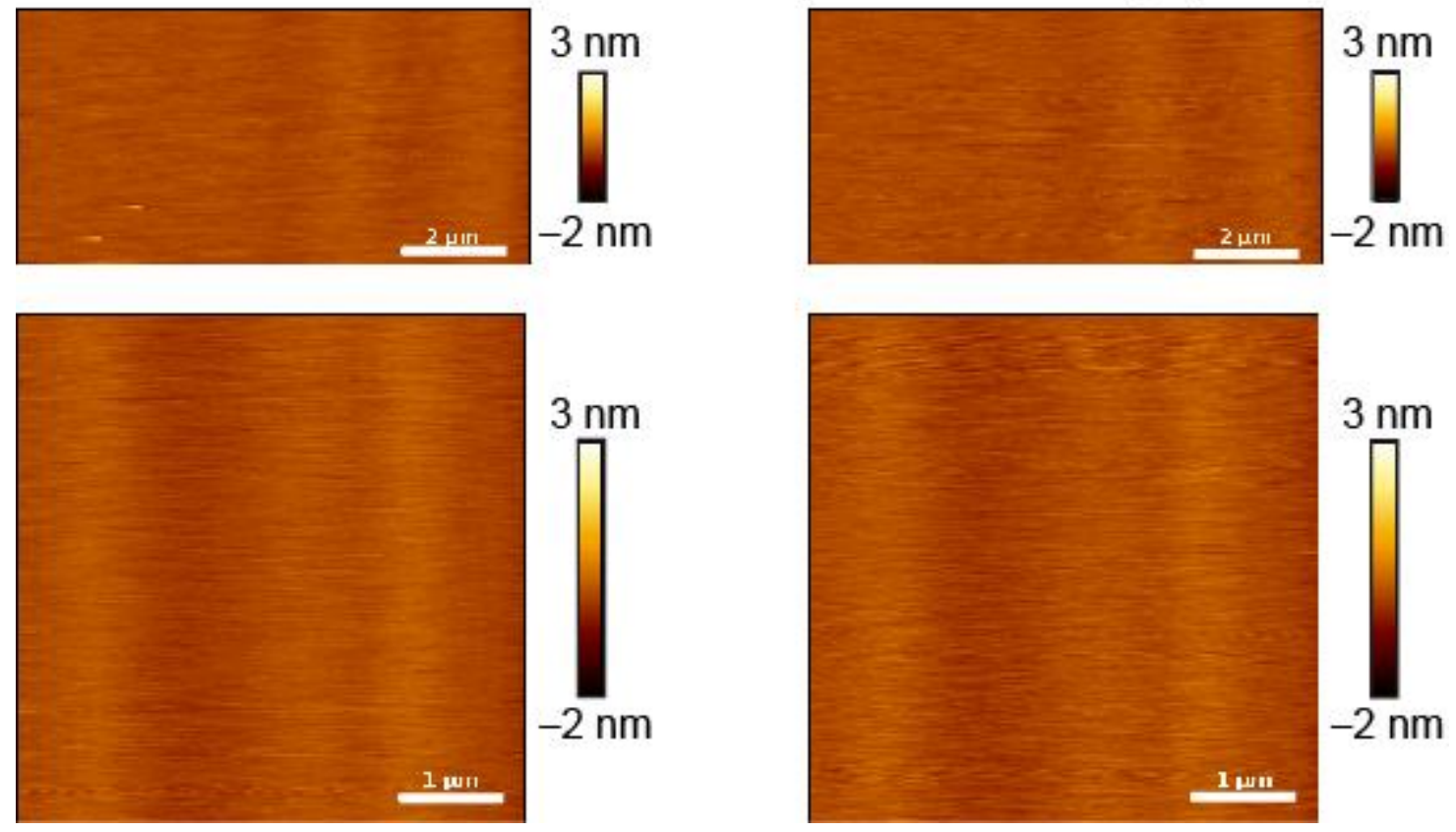

Figure S7. Lipid bilayers containing a 5:5 SM:ACe-2 ratio do not form ordered domains. DOPC:Chol:SM:ACe-2 (10:6.7:5:5 mol ratio) lipid mixtures were analyzed by high-speed AFM and representative AFM images are displayed. Only a single fluid phase was observed, and the SLB was not affected by $\lambda=365 \mathrm{~nm}$ irradiation. Scale bars $=2 \mu \mathrm{m}$ (top) or $1 \mu \mathrm{m}$ (bottom). 


\section{Supplementary Movie Legends}

Supplementary Movie S1. ACe-1 permits reversible remodelling of lipid domains. An SLB containing a DOPC:Chol:SM:ACe-1 (10:6.7:5:5 mol ratio) lipid mixture was analyzed using high-speed AFM in intermittent-contact mode (AC mode). On isomerization to cis-ACe-1 (gray circle) with $\lambda=365 \mathrm{~nm}$ irradiation, small $L_{d}$ lakes were immediately formed within the $L_{o}$ domains. The lakes were dynamic and fused together into larger $L_{d}$ lakes. On isomerization back to trans-ACe-1 with $\lambda=470 \mathrm{~nm}$ blue light (blue circle), small transient $L_{o}$ islands appeared within the larger $L_{d}$ domains. This effect could be repeated over multiple cycles. Scale bar $=1 \mu \mathrm{m}$. Acquisition $=13 \mathrm{~s} / \mathrm{frame}$. Video frame rate $=7 \mathrm{fps}$.

Supplementary Movie S2. Reversible remodelling of lipid domains by ACe-1 on a DOPC:Chol:SM:ACe-1 (10:6.7:5:5 mol ratio) lipid mixture, recorded using high-speed AFM. The isomerization to cis-ACe-1 is marked with a gray circle; isomerization back to trans-ACe-1 is marked with a blue circle. Scale bar $=500 \mathrm{~nm}$. Acquisition $=0.53 \mathrm{~s} /$ frame. Video frame rate $=15 \mathrm{fps}$.

Supplementary Movie S3. Remodelling of lipid domains by ACe-2 on a DOPC:Chol:SM:ACe-2 (10:6.7:7:3 mol ratio) lipid mixture, recorded using high-speed AFM. The isomerization to cis-ACe-2 is marked with a gray circle; isomerization back to trans-ACe-2 is marked with a blue circle. Scale bar $=1 \mu \mathrm{m}$. Acquisition $=8 \mathrm{~s} /$ frame. Video frame rate $=11 \mathrm{fps}$.

Supplementary Movie S4. Remodelling of lipid domains by ACe-3 on a DOPC:Chol:SM:ACe-3 (10:6.7:7:3 mol ratio) lipid mixture, recorded using high-speed AFM. The isomerization to cis-ACe-3 is marked with a gray circle; isomerization back to trans-ACe-3 is marked with a blue circle. Scale bar $=1 \mu \mathrm{m}$. Acquisition $=6.5 \mathrm{~s} /$ frame. Video frame rate $=11 \mathrm{fps}$. 
Supplementary Movie S5. Remodelling of lipid domains by ACe-3 on a DOPC:Chol:SM:ACe-3 (10:6.7:5:5 mol ratio) lipid mixture, recorded using high-speed AFM. The isomerization to cis-ACe-3 is marked with a gray circle; isomerization back to trans-ACe-3 is marked with a blue circle. Scale bar $=1 \mu \mathrm{m}$. Acquisition $=16 \mathrm{~s} /$ frame. Video frame rate $=9 \mathrm{fps}$. 


\section{Experimental section}

\section{Supported lipid bilayer formation}

N-Stearoyl-D-erythro-sphingosine (C18-Cer), N-stearoyl-D-erythro-sphingosylphosphorylcholine (C18-SM, or simply SM), 1,2-dioleoyl-sn-glycero-3-phosphocholine (DOPC) and cholesterol (Chol) were purchased

from Avanti Polar Lipids (Alabaster, AL, USA). Supported lipid bilayers (SLBs) were prepared by deposition and fusion of small unilamellar vesicles (SUVs) as described elsewhere ${ }^{1}$. SUVs composed of DOPC:Chol:SM:C18-Cer and DOPC:Chol:SM:ACe, containing additional 0.1 mol\% ATTO655-DOPE (ATTO Technology GmbH, Siegen, Germany), were obtained through bath sonication of multilamellar vesicles. SUV suspensions ( $1 \mathrm{mM}$ total lipid concentration diluted in a $10 \mathrm{mM} \mathrm{HEPES}, 150 \mathrm{mM} \mathrm{NaCl}$, $\mathrm{pH} 7.4$ buffer) were deposited in the presence of $2 \mathrm{mM} \mathrm{CaCl}_{2}$ on freshly-cleaved mica previously glued to glass coverslips. The samples were incubated for $30 \mathrm{~min}$ at $65^{\circ} \mathrm{C}$, rinsed with buffer and were then allowed to cool slowly to room temperature for at least $1 \mathrm{~h}$.

SUV size (z-average) was measured at a total $66.7 \mu \mathrm{M}$ lipid concentration via dynamic light scattering, utilizing a Malvern Zetasizer Nano ZSP (Malvern, Worcestershire, UK) with Hellma SUPRASIL precision quartz cuvettes (10 $\mathrm{mm}$ light path). 


\section{Combined Atomic Force and Confocal Microscopy}

Combined atomic force and confocal microscopy was performed on a JPK Instruments Nanowizard III BioAFM and Nanowizard Ultra (Berlin, Germany) mounted on a Zeiss LSM510 Meta laser scanning confocal microscope (Jena, Germany). Contact-mode AFM imaging was performed with the Nanowizard III head, using uncoated silicon cantilevers CSC38 from MikroMasch (Tallinn, Estonia) with typical spring constants of 0.01-0.2 N/m. The scan rate was typically set between 2-10 Hz. High-speed AFM in AC mode was done with the Nanowizard Ultra head, utilizing USC-F0.3-k0.3 ultra-short cantilevers from Nanoworld (Neuchâtel, Switzerland) with typical stiffness of $0.3 \mathrm{~N} / \mathrm{m}$. The cantilever oscillation was tuned to a frequency of $100-150 \mathrm{kHz}$ and the amplitude kept below $10 \mathrm{~nm}$. Scan rate was set to $25-150 \mathrm{~Hz}$. For both modes, images were acquired with a typical $256 \times 256$ pixel resolution. All measurements were performed at room temperature. The force applied on the sample was minimized by continuously adjusting the set point and gain during imaging. Height, error, deflection and phase-shift signals were recorded and images were line-fitted as required. Data was analyzed using JPK data

processing software Version 5.1.4 (JPK Instruments) and Gwyddion Version 2.30 (Czech Metrology Institute).

For the confocal measurements, a $\lambda=633 \mathrm{~nm}$ He-Ne laser (to excite the $0.1 \mathrm{~mol} \%$ ATTO655DOPE added to the lipid mixtures) and a 40× NA 1.2 UV-VIS-IR C Apochromat water-immersion objective were used. All measurements were performed at room temperature. Images were typically acquired with a $512 \times 512$ pixel resolution at a scan rate of $3.2 \mu$ s per pixel and using a 1 Airy pinhole. Images were further processed with Fiji software (http://fiji.sc/Fiji) and the resulting data was analyzed in Microsoft Excel. The data was then plotted using Igor Pro. 


\section{Compound Switching on Supported Lipid Bilayers}

Compound switching for combined atomic force and confocal microscopy was achieved using a CoolLED pE-2 LED light source (Andover, United Kingdom) for illumination at $\lambda=365,425$ and $470 \mathrm{~nm}$. The lightsource was operated at a maximum of $80 \%$ power. The light beam was guided by a fiber-optic cable directly through the objective of the microscope via a collimator at the backport side of the microscope. 


\section{Compound Synthesis and Characterization}

All reagents and solvents were purchased from commercial sources (Sigma-Aldrich, TCl Europe N.V., Strem Chemicals, etc.) and were used without further purification unless otherwise noted. Triethylamine $\left(\mathrm{NEt}_{3}\right)$ was distilled under a $\mathrm{N}_{2}$ atmosphere from $\mathrm{CaH}_{2}$ prior to use. Further dry solvents such as ethyl acetate (EtOAc), were purchased from Acros Organics as "extra dry" reagents and used as received. Reactions were monitored by TLC on pre-coated, Merck Silica gel $60 \mathrm{~F}_{254}$ glass backed plates and the chromatograms were first visualized by UV irradiation at $\lambda=254 \mathrm{~nm}$, followed by staining with aqueous ceric ammonium molybdate solution, and finally gentle heating with a heat gun. Flash silica gel chromatography was performed using silica gel $\left(\mathrm{SiO}_{2}\right.$, particle size $\left.40-63 \mu \mathrm{m}\right)$ purchased from Merck.

All NMR spectra were measured on a BRUKER Avance III HD 400 (equipped with a CryoProbe $^{\mathrm{TM}}$ ). Multiplicities in the following experimental procedures are abbreviated as follows: $\mathrm{s}=$ singlet, $\mathrm{d}=$ doublet, $\mathrm{t}=$ triplet, $\mathrm{q}=$ quartet, quint $=$ quintet, sext $=$ sextet, hept $=$ heptet, $\mathrm{br}=$ broad, $\mathrm{m}=$ multiplet. Proton chemical shifts are expressed in parts per million (ppm, $\delta$ scale) and are referenced to the residual protium in the NMR solvent $\left(\mathrm{CDCl}_{3}: \delta=7.26\right.$, THF- $\left.\mathrm{d}_{8}: \delta=3.58\right)$. Carbon chemical shifts are expressed in ppm ( $\delta$ scale) and are referenced to the carbon resonance of the NMR solvent $\left(\mathrm{CDCl}_{3}: \delta=77.16\right.$, THF-d $\left.: \delta=67.21\right)$. NOTE: Due to the trans/cis isomerisation of some compounds containing an azobenzene functionality, more signals were observed in the ${ }^{1} \mathrm{H}$ and ${ }^{13} \mathrm{C}$ spectra than would be expected for the pure trans-isomer. Only signals for the major trans-isomer are reported, however the identities of the remaining peaks were verified by $2 D$ COSY, HSQC and HMBC experiments.

Infrared (IR) spectra were recorded as neat materials on a PERKIN ELMER Spectrum BX-59343 instrument. For detection a SMITHS DETECTION DuraSam-pIIR II Diamond ATR sensor was used. The measured wave numbers are reported in $\mathrm{cm}^{-1}$.

Low- and high-resolution El mass spectra were obtained on a MAT CH7A mass spectrometer. Low- and high-resolution ESI mass spectra were obtained on a Varian MAT 711 MS instrument operating in either positive or negative ionization modes. 
UV-Vis spectra were recorded using a Varian Cary 50 Bio UV-Visible Spectrophotometer with Hellma SUPRASIL precision cuvettes (10 mm light path). Switching was achieved using a Polychrome V (Till Photonics) monochromator ${ }^{2}$ using PolyCon3.1 software (5 min irradiation time) or the CoolLED pE-2 LED light source (80\% power, $30 \mathrm{~s}$ irradiation). The light was guided through a fiber-optic cable with the tip pointed directly into the top of the sample cuvette. An initial spectrum was recorded (dark-adapted state, black) and then again following illumination at $\lambda=365 \mathrm{~nm}$ for $30 \mathrm{~s}$ (cis-adapted state, gray). A third spectrum was recorded after irradiation at $\lambda=470 \mathrm{~nm}$ for $30 \mathrm{~s}$ (trans-adapted state, blue). 


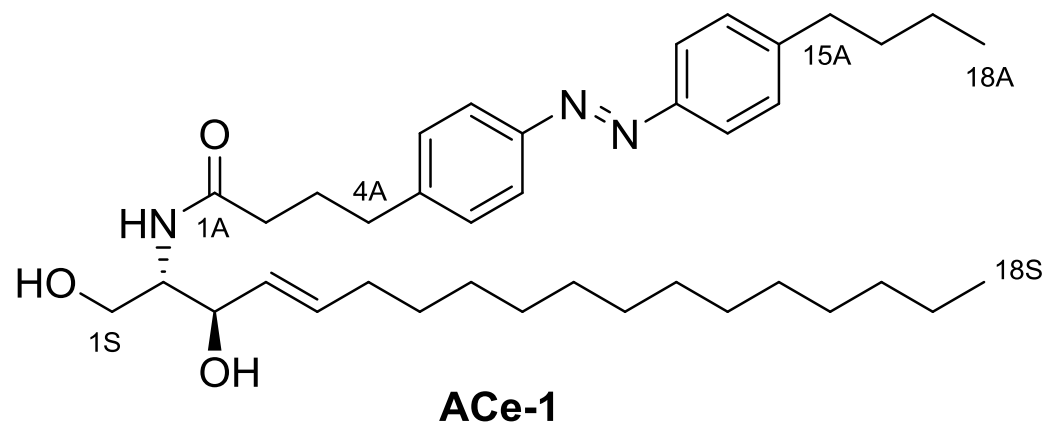

A solution of 4-((4-butylphenyl)diazenyl)phenyl)butanoic acid (FAAzo-4, 20 mg, $62 \mu \mathrm{mol}, 1.0$ equiv.) and TBTU (20 mg, $62 \mu \mathrm{mol}, 1.0$ equiv.) in EtOAc (3.0 mL) was treated with $\mathrm{NEt}_{3}(25 \mathrm{mg}, 4.0$ equiv.) under an argon atmosphere at room temperature. After $1 \mathrm{~h}$, D-erythro-sphingosine $(24 \mathrm{mg}, 0.78 \mathrm{mmol}$, 1.25 equiv.) was added and stirring was continued at room temperature for $4 \mathrm{~h}$. The solution was then diluted with EtOAc $(30 \mathrm{~mL})$ and washed with aqueous $\mathrm{NaHCO}_{3}(2 \times 20 \mathrm{~mL})$ and brine $(2 \times 20 \mathrm{~mL}, 50 \%$ saturated) solutions. The phases were separated and the organic solvents were removed under reduced pressure. The residue was then purified by flash silica gel chromatography $\left(3.0 \mathrm{~g} \mathrm{SiO}_{2}\right.$, 3:1 EtOAc:hexanes) to yield $\quad \boldsymbol{N}$-(4-((4-butylphenyl)diazenyl)phenyl)butanamide)-(2S,3R)-2aminooctadec-4-ene-1,3-diol (ACe-1, $26 \mathrm{mg}, 70 \%$ ) as an orange oil. 
TLC (EtOAc:hexanes, 4:1): $\mathrm{R}_{\mathrm{f}}=0.39$.

${ }^{1} \mathrm{H}_{\mathrm{NMR}}\left(\mathrm{CDCl}_{3}, 400 \mathrm{MHz}, 25^{\circ} \mathrm{C}\right): \delta 7.81\left(\mathrm{~d}, 4 \mathrm{H}, \mathrm{H} 7 \mathrm{~A}_{\mathrm{a}, \mathrm{b}}, \mathrm{H} 12 \mathrm{~A}_{\mathrm{a}, \mathrm{b}}, \mathrm{J}=8.1 \mathrm{~Hz}\right), 7.33-7.28\left(\mathrm{~m}, 4 \mathrm{H}, \mathrm{H} 6 \mathrm{~A}_{\mathrm{a}, \mathrm{b}}\right.$, $\left.\mathrm{H}_{13 \mathrm{~A}_{\mathrm{a}, \mathrm{b}}}\right), 6.33(\mathrm{~d}, 1 \mathrm{H}, \mathrm{NH}, \mathrm{J}=7.4 \mathrm{~Hz}), 5.80-5.71(\mathrm{~m}, 1 \mathrm{H}, \mathrm{H} 5 \mathrm{~S}), 5.50$ (dd, $\left.1 \mathrm{H}, \mathrm{H} 4 \mathrm{~S}, \mathrm{~J}=15.4,6.3 \mathrm{~Hz}\right)$, 4.29-4.25 (m, $1 \mathrm{H}, \mathrm{H} 3 \mathrm{~S}), 3.95-3.86$ (m, $2 \mathrm{H}, \mathrm{H} 2 \mathrm{~S}, \mathrm{H} 1 \mathrm{~S}_{\mathrm{a}}$ ), 3.67 (dd, $1 \mathrm{H}, \mathrm{H} 1 \mathrm{~S}_{\mathrm{b}}, \mathrm{J}=10.9,3.1 \mathrm{~Hz}$ ), 3.12 ( $\mathrm{S}_{\text {brd }}$, $2 \mathrm{H}, 2 \times \mathrm{OH}$ ), 2.76-2.50 (m, $4 \mathrm{H}, \mathrm{H} 4 \mathrm{~A}_{\mathrm{a}, \mathrm{b}}, \mathrm{H} 15 \mathrm{~A}_{\mathrm{a}, \mathrm{b}}$ ), 2.29-2.17 (m, $\left.2 \mathrm{H}, \mathrm{H} 2 \mathrm{~A}_{\mathrm{a}, \mathrm{b}}\right)$, 2.07-1.96 (m, $4 \mathrm{H}, \mathrm{H}_{\mathrm{aS}}$, $\left.\mathrm{H} 3 \mathrm{~A}_{\mathrm{a}, \mathrm{b}}\right), 1.69-1.50\left(\mathrm{~m}, 2 \mathrm{H}, \mathrm{H} 16 \mathrm{~A}_{\mathrm{a}, \mathrm{b}}\right), 1.44-1.66\left(\mathrm{~m}, 24 \mathrm{H}, \mathrm{H}_{\mathrm{Alk}}\right), 0.94\left(\mathrm{t}, 3 \mathrm{H}, \mathrm{H} 18 \mathrm{~A}_{\mathrm{a}, \mathrm{b}, \mathrm{c}}\right), 0.90-0.85(\mathrm{~m}, 3 \mathrm{H}$,

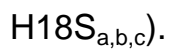

${ }^{13} \mathrm{C}$ NMR $\left(\mathrm{CDCl}_{3}, 100 \mathrm{MHz}, 25^{\circ} \mathrm{C}\right): \delta 173.4(\mathrm{C} 1 \mathrm{~A}), 151.4\left(\mathrm{C}_{\mathrm{Azo}}\right), 151.0\left(\mathrm{C}_{\mathrm{Azo}}\right), 146.5\left(\mathrm{C}_{\mathrm{Azo}}\right), 144.6\left(\mathrm{C}_{\mathrm{Azo}}\right)$,

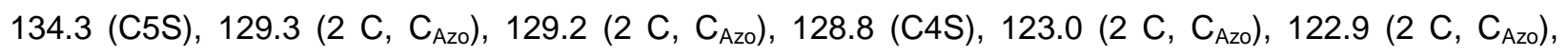
74.6 (C3S), 62.5 (C1S), 54.5 (C2S), 35.9 (C2A), $35.7\left(\mathrm{C}_{\mathrm{Alk}}\right), 35.1\left(\mathrm{C}_{\mathrm{Alk}}\right), 33.6(\mathrm{C} 16 \mathrm{~A}), 32.4(\mathrm{C} 6 \mathrm{~S})$, $32.1\left(C_{A \mid k}\right), 29.83\left(2 C, C_{A \mid k}\right), 29.80\left(C_{A \mid k}\right), 29.77\left(C_{A \mid k}\right), 29.6\left(C_{A l k}\right), 29.5\left(C_{A \mid k}\right), 29.4\left(C_{A \mid k}\right), 29.3\left(C_{A \mid k}\right), 27.0$ $\left(\mathrm{C}_{\mathrm{Alk}}\right), 22.8\left(\mathrm{C}_{\mathrm{Alk}}\right), 22.5\left(\mathrm{C}_{\mathrm{Alk}}\right), 14.3(\mathrm{C} 18 \mathrm{~A}), 14.1(\mathrm{C} 18 \mathrm{~S})$.

IR (neat, ATR): $\tilde{v}=3291,2954,2918,2849,1640,1602,1548,1497,1466,1454,1435,1417,1377$, 1284, 1224, 1199, 1155, 1107, 1070, 1036, 1013, 982, 959, 914, 850, 839, 721.

HRMS (EI): $m / z$ calcd. for $\left[\mathrm{C}_{28} \mathrm{H}_{33} \mathrm{~N}_{3} \mathrm{O}_{3}\right]: 605.4556$, found: $605.4563\left(\left[\mathrm{M}-\mathrm{e}^{-}\right]^{+}\right)$.

UV-Vis $\left(50 \mu\right.$ in DMSO): $\lambda_{\max }\left(\pi-\pi^{*}\right)=340 \mathrm{~nm} \cdot \lambda_{\max }\left(\mathrm{n}-\pi^{*}\right)=435 \mathrm{~nm}$. 


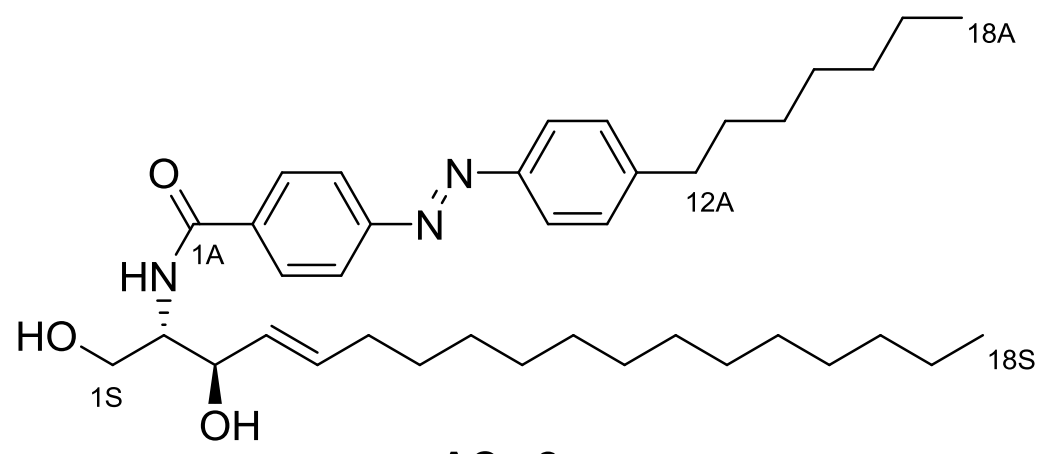

$\mathrm{ACe}-2$

N-(4-((4-Heptylphenyl)diazenyl)benzamide)-(2S,3R)-2-aminooctadec-4-ene-1,3-diol $\quad(\mathrm{ACe}-2) \quad$ was prepared from 4-((4-heptylphenyl)diazenyl)benzoic acid (FAAzo-1, $25.2 \mathrm{mg}, 0.078 \mathrm{mmol}, 1$ equiv.) as described above in the synthesis of $N$-(4-(((4-butylphenyl)diazenyl)phenyl)butanamide)-(2S,3R)-2aminooctadec-4-ene-1,3-diol (ACe-1). ACe-2 (43.3 mg, 92\%) was isolated as an orange oil. NOTE: all reactants and reagents were scaled according to molarity. 
TLC (EtOAc:hexanes 9:1): $R_{f}=0.31$.

${ }^{1}$ H NMR (THF, 400 MHz, $25^{\circ} \mathrm{C}$ ): $\delta 8.01\left(\mathrm{~d}, 2 \mathrm{H}, \mathrm{H}_{\text {Azo }}, \mathrm{J}=8.3 \mathrm{~Hz}\right.$ ), $7.91\left(\mathrm{~d}, 2 \mathrm{H}, \mathrm{H}_{\text {Azo }}, \mathrm{J}=8.2 \mathrm{~Hz}\right), 7.86(\mathrm{~d}$, $\left.2 \mathrm{H}, \mathrm{H}_{\text {Azo }}, \mathrm{J}=8.1 \mathrm{~Hz}\right), 7.49\left(\mathrm{~d}, 1 \mathrm{H}, \mathrm{H}_{\mathrm{NH}}, \mathrm{J}=8.2 \mathrm{~Hz}\right), 7.36\left(\mathrm{~d}, 2 \mathrm{H}, \mathrm{H}_{\text {Azo }}, \mathrm{J}=8.1 \mathrm{~Hz}\right), 5.77-5.67(\mathrm{~m}, 1 \mathrm{H}$, H5S), 5.59 (dd, $1 \mathrm{H}, \mathrm{H} 4 \mathrm{~S}, \mathrm{~J}=15.6,6.3 \mathrm{~Hz}), 4.39\left(\mathrm{~d}, 1 \mathrm{H}, \mathrm{OH}_{(3)}, \mathrm{J}=5.0 \mathrm{~Hz}\right), 4.26(\mathrm{q}, 1 \mathrm{H}, \mathrm{H} 3 \mathrm{~S}$, $\mathrm{J}=5.5 \mathrm{~Hz}), 4.08-4.00(\mathrm{~m}, 1 \mathrm{H}, \mathrm{H} 2 \mathrm{~S}), 3.97\left(\mathrm{t}, 1 \mathrm{H}, \mathrm{OH}_{(1)}, \mathrm{J}=5.5 \mathrm{~Hz}\right), 3.91-3.84\left(\mathrm{~m}, 1 \mathrm{H}, \mathrm{H}_{1} \mathrm{~S}_{\mathrm{a}}\right), 3.75-3.68$ (m, $1 \mathrm{H}, \mathrm{H}_{1} \mathrm{~S}_{\mathrm{b}}$ ), 2.70 (t, $\left.2 \mathrm{H}, \mathrm{H} 12 \mathrm{~A}, \mathrm{~J}=7.9 \mathrm{~Hz}\right), 2.06-1.96$ (m, $2 \mathrm{H}, \mathrm{H}_{\mathrm{a}} \mathrm{b}$ ), 1.72-1.63 (m, $2 \mathrm{H}, \mathrm{H} 13 \mathrm{~A}_{\mathrm{a}, \mathrm{b}}$ ), 1.40-1.20 (m, $\left.30 \mathrm{H}_{\mathrm{Alk}}\right), 0.94-0.82\left(\mathrm{~m}, 6 \mathrm{H}, \mathrm{H} 18 \mathrm{~A}_{\mathrm{a}, \mathrm{b}, \mathrm{c}}, \mathrm{H} 18 \mathrm{~S}_{\mathrm{a}, \mathrm{b}, \mathrm{c}}\right)$.

${ }^{13} \mathrm{C}$ NMR $\left(\mathrm{CDCl}_{3}, 100 \mathrm{MHz}, 25^{\circ} \mathrm{C}\right): \delta 166.7(\mathrm{C} 1 \mathrm{~A}), 154.9\left(\mathrm{C}_{\mathrm{Azo}}\right), 151.9\left(\mathrm{C}_{\text {Azo }}\right), 148.0\left(\mathrm{C}_{\text {Azo }}\right), 138.2\left(\mathrm{C}_{\text {Azo }}\right)$, 132.5 (2 C, C4S, C5S), 130.0 (2 C, $\mathrm{C}_{\text {Azo }}$ ), 129.2 (2 C, $\mathrm{C}_{\text {Azo }}$ ), 123.9 (2 C, $\mathrm{C}_{\text {Azo }}$ ), 123.2 (2 C, $\left.\mathrm{C}_{\text {Azo }}\right), 73.8$ (C3S), 62.2 (C1S), 57.3 (C2S), 36.7 (C12A), $33.3(\mathrm{C} 6 \mathrm{~S}), 32.9\left(\mathrm{C}_{\mathrm{Alk}}\right), 32.8\left(\mathrm{C}_{\mathrm{Alk}}\right), 32.3(\mathrm{C} 13 \mathrm{~A}), 30.8\left(\mathrm{C}_{\mathrm{Alk}}\right)$, $30.72\left(\mathrm{C}_{\text {Alk }}\right), 30.67\left(\mathrm{C}_{\text {Alk }}\right), 30.65\left(\mathrm{C}_{\text {Alk }}\right), 30.61\left(\mathrm{C}_{\text {Alk }}\right), 30.5\left(\mathrm{C}_{\mathrm{Alk}}\right), 30.4\left(\mathrm{C}_{A \mid k}\right), 30.3\left(\mathrm{C}_{A \mid k}\right), 30.22\left(\mathrm{C}_{A \mid k}\right), 30.19$ $\left(\mathrm{C}_{\mathrm{Alk}}\right), 23.63\left(\mathrm{C}_{\mathrm{Alk}}\right), 23.60\left(\mathrm{C}_{\mathrm{Alk}}\right), 14.53(\mathrm{C} 18), 14.51(\mathrm{C} 18)$.

IR (neat, ATR): $\tilde{v}=3677,3634,3301,2955,2850,1634,1604,1575,1539,1493,1466,1414,1341$, $1300,1259,1222,1154,1101,1047,1012,965,858,821,770,721$.

HRMS (EI $\left.{ }^{+}\right): m / z$ calcd. for $\left[\mathrm{C}_{38} \mathrm{H}_{60} \mathrm{~N}_{3} \mathrm{O}_{3}\right]^{+}: 606.4635$, found: $606.4636\left([\mathrm{M}-\mathrm{e}]^{+}\right)$.

UV-Vis (50 $\mu$ M in DMSO): $\lambda_{\max }\left(\pi-\pi^{*}\right)=340 \mathrm{~nm} \cdot \lambda_{\max }\left(\mathrm{n}-\pi^{*}\right)=435 \mathrm{~nm}$. 


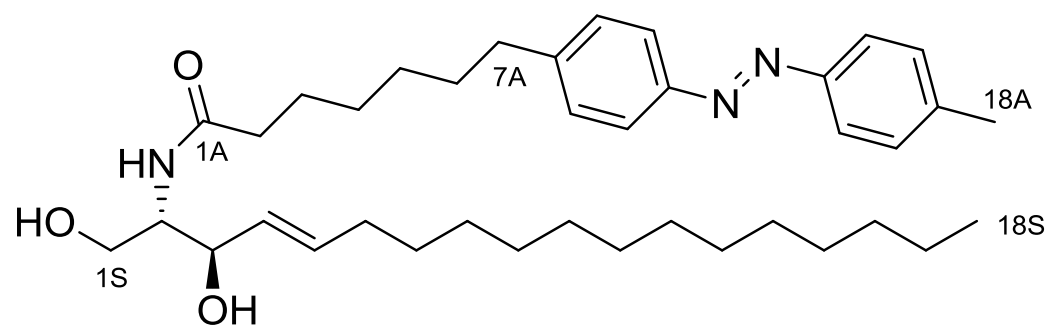

$\mathrm{ACe}-3$

$N$-(7-(4-(p-Tolyldiazenyl)phenyl)heptanamide)-(2S,3R)-2-aminooctadec-4-ene-1,3-diol (ACe-3) was prepared from 7-(4-(p-tolyldiazenyl)phenyl)heptanoic acid (FAAzo-7, $9.0 \mathrm{mg}, 0.028 \mathrm{mmol}, 1$ equiv.) as described above in the synthesis of $N-(4-((4-B u t y l p h e n y l)$ diazenyl)phenyl)butanamide)-(2S,3R)-2aminooctadec-4-ene-1,3-diol (ACe-1). ACe-3 (16.5 mg, 97\%) was isolated as an orange solid. NOTE: all reactants and reagents were scaled according to molarity. 
TLC (9:1 EtOAc:hexanes): $\mathrm{R}_{\mathrm{f}}=0.41$.

${ }^{1} \mathbf{H}$ NMR $\left(\mathrm{CDCl}_{3}, 400 \mathbf{M H z}, 25{ }^{\circ} \mathrm{C}\right): \delta 7.84-7.78\left(\mathrm{~m}, 4 \mathrm{H}, \mathrm{H} 10_{a, b}, \mathrm{H} 15 \mathrm{~A}_{\mathrm{a}, \mathrm{b}}\right), 7.33-7.28\left(\mathrm{~m}, 4 \mathrm{H}, \mathrm{H} 9 \mathrm{~A}_{\mathrm{a}, \mathrm{b}}\right.$, $\left.H_{16 A_{a, b}}\right), 6.25\left(d, 1 \mathrm{H}, \mathrm{H}_{N H}, \mathrm{~J}=7.4 \mathrm{~Hz}\right), 5.82-5.71(\mathrm{~m}, 1 \mathrm{H}, \mathrm{H} 5 \mathrm{~S}), 5.52(\mathrm{dd}, 1 \mathrm{H}, \mathrm{H} 4 \mathrm{~S}, \mathrm{~J}=15.5,6.3 \mathrm{~Hz}$ ), 4.33-4.27 (m, $1 \mathrm{H}, \mathrm{H} 3 \mathrm{~S}), 3.98-3.86$ (m, $2 \mathrm{H}, \mathrm{H} 2 \mathrm{~S}, \mathrm{H} 1 \mathrm{~S}_{\mathrm{a}}$ ), 3.68 (dd, $\left.1 \mathrm{H}, \mathrm{H} 15 \mathrm{~A}, \mathrm{~J}=11.2,3.2 \mathrm{~Hz}\right), 2.79$ (s $\mathrm{s}_{(\mathrm{br})}$, $2 \mathrm{H}, 2 \times \mathrm{OH}$ ), 2.67 (t, $2 \mathrm{H}, \mathrm{H} 7 \mathrm{~A}_{\mathrm{a}, \mathrm{b}}, \mathrm{J}=7.5 \mathrm{~Hz}$ ), 2.43 (s, 3 H, H18A $\mathrm{a}_{\mathrm{a}, \mathrm{b}, \mathrm{c}}$ ), 2.22 (t, $2 \mathrm{H}, \mathrm{H} 2 \mathrm{~A}_{\mathrm{a}, \mathrm{b}}, \mathrm{J}=7.6 \mathrm{~Hz}$ ), 2.08-2.00 (m, $\left.2 \mathrm{H}, \mathrm{H} 6 \mathrm{~S}_{\mathrm{a}, \mathrm{b}}\right), 1.71-1.59\left(\mathrm{~m}, 4 \mathrm{H}, \mathrm{H} 6 \mathrm{~A}_{\mathrm{a}, \mathrm{b}}, \mathrm{H} 3 \mathrm{~A}_{\mathrm{a}, \mathrm{b}}\right), 1.43-1.18\left(\mathrm{~m}, 26 \mathrm{H}, \mathrm{H}_{\text {Alk }}\right.$ ), 0.87 (t, $3 \mathrm{H}$, $\left.\mathrm{H} 18 \mathrm{~S}_{\mathrm{a}, \mathrm{b}, \mathrm{c}}, \mathrm{J}=7.2 \mathrm{~Hz}\right)$.

${ }^{13} \mathrm{C}$ NMR $\left(\mathrm{CDCl}_{3}, 100 \mathrm{MHz}, 25{ }^{\circ} \mathrm{C}\right): \delta 173.9\left(\mathrm{C}_{\mathrm{Azo}}\right), 151.1\left(\mathrm{C}_{\mathrm{Azo}}\right), 151.0\left(\mathrm{C}_{\mathrm{Azo}}\right), 146.1\left(\mathrm{C}_{\mathrm{Azo}}\right), 141.4\left(\mathrm{C}_{\mathrm{Azo}}\right)$, $143.4\left(\mathrm{C}_{\text {Azo }}\right), 134.4(\mathrm{C} 5 \mathrm{~S}), 129.9\left(2 \mathrm{C}, \mathrm{C}_{\text {Azo }}\right), 129.2\left(2 \mathrm{C}, \mathrm{C}_{\text {Azo }}\right), 128.9(\mathrm{C} 4 \mathrm{~S}), 122.9\left(4 \mathrm{C}, \mathrm{C}_{\text {Azo }}\right), 74.9(\mathrm{C} 3 \mathrm{~S})$, 62.6 (C1S), 54.5 (C2S), 36.8 (C2A), 35.9 (C7A), 32.4 (C6S), $32.1\left(\mathrm{C}_{\mathrm{Alk}}\right), 31.2\left(\mathrm{C}_{\mathrm{Alk}}\right), 29.85\left(\mathrm{C}_{\mathrm{Alk}}\right), 29.84$ $\left(C_{A \mid k}\right), 29.82\left(C_{A \mid k}\right), 29.81\left(C_{A \mid k}\right), 29.77\left(C_{A \mid k}\right), 29.64\left(C_{A \mid k}\right), 29.51\left(C_{A \mid k}\right), 29.37\left(C_{A \mid k}\right), 29.25\left(C_{A \mid k}\right), 29.19$ $\left(\mathrm{C}_{\mathrm{Alk}}\right), 29.01\left(\mathrm{C}_{\mathrm{Alk}}\right), 25.7\left(\mathrm{C}_{\mathrm{Alk}}\right), 22.9\left(\mathrm{C}_{\mathrm{Alk}}\right), 21.7(\mathrm{C} 18 \mathrm{~A}), 14.2(\mathrm{C} 18 \mathrm{~S})$.

IR (neat, ATR): $\tilde{v}=3564,3294,2919,2850,1634,1603,1539,1466,1359,1155,1104,1012,963,855$, 721.

HRMS (ESI $\left.{ }^{+}\right): m / z$ calcd. for $\left[\mathrm{C}_{38} \mathrm{H}_{59} \mathrm{~N}_{3} \mathrm{O}_{3}\right]^{+}: 605.4635$, found: $606.4635\left(\left[\mathrm{M}+\mathrm{H}^{+}\right]^{+}\right)$.

UV-Vis (50 $\mu$ M in DMSO): $\lambda_{\max }\left(\pi-\pi^{*}\right)=340 \mathrm{~nm} . \lambda_{\max }\left(\mathrm{n}-\pi^{\star}\right)=435 \mathrm{~nm}$.

Melting point $\left({ }^{\circ} \mathrm{C}\right): 103-105$. 


\section{NMR Spectra}

N-(4-(((4-Butylphenyl)diazenyl)phenyl)butanamide)-(2S,3R)-2-aminooctadec-4-ene-1,3-diol (ACe-1)

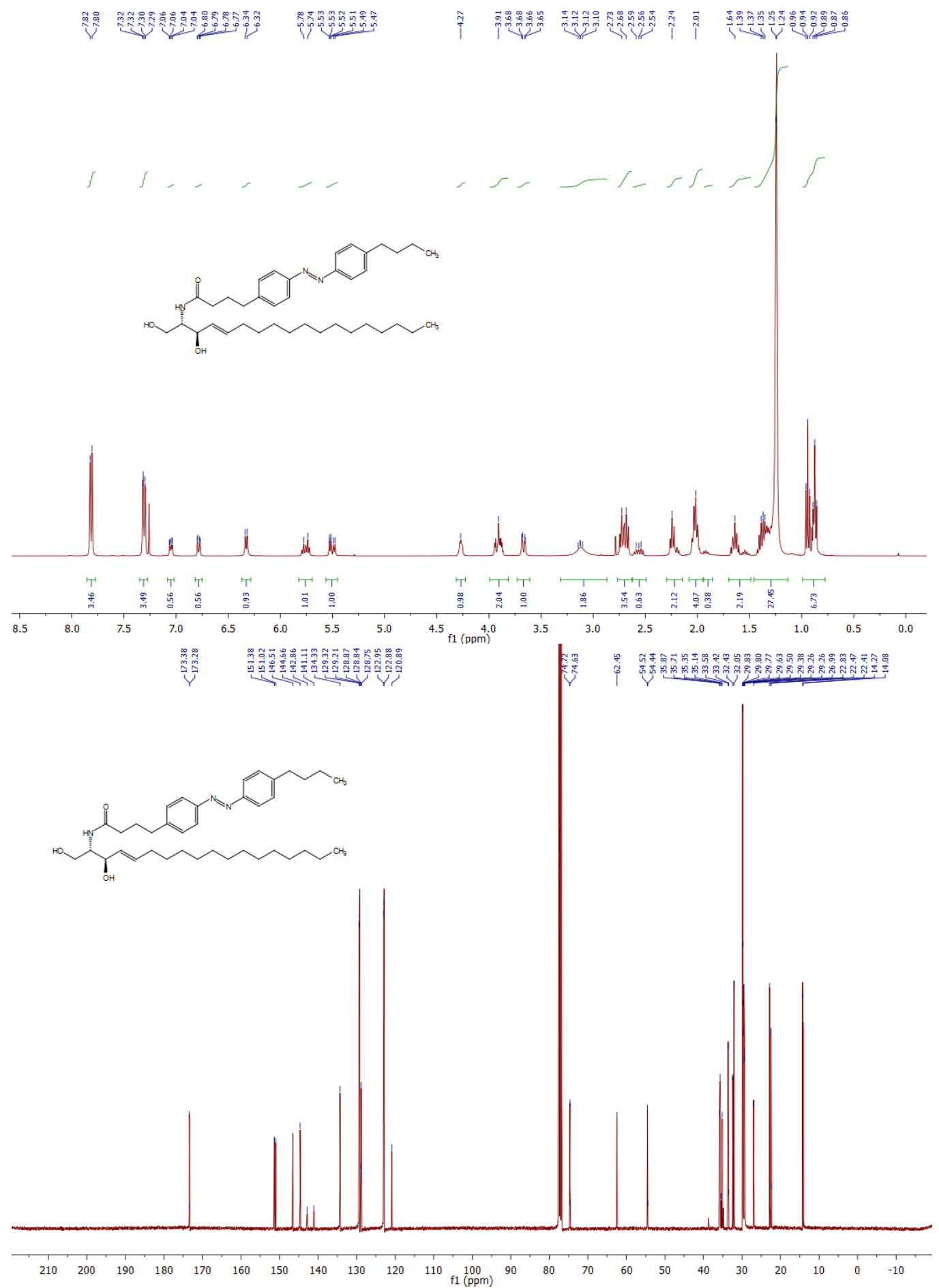


N-(4-((4-Heptylphenyl)diazenyl)benzamide)-(2S,3R)-2-aminooctadec-4-ene-1,3-diol (ACe-2)
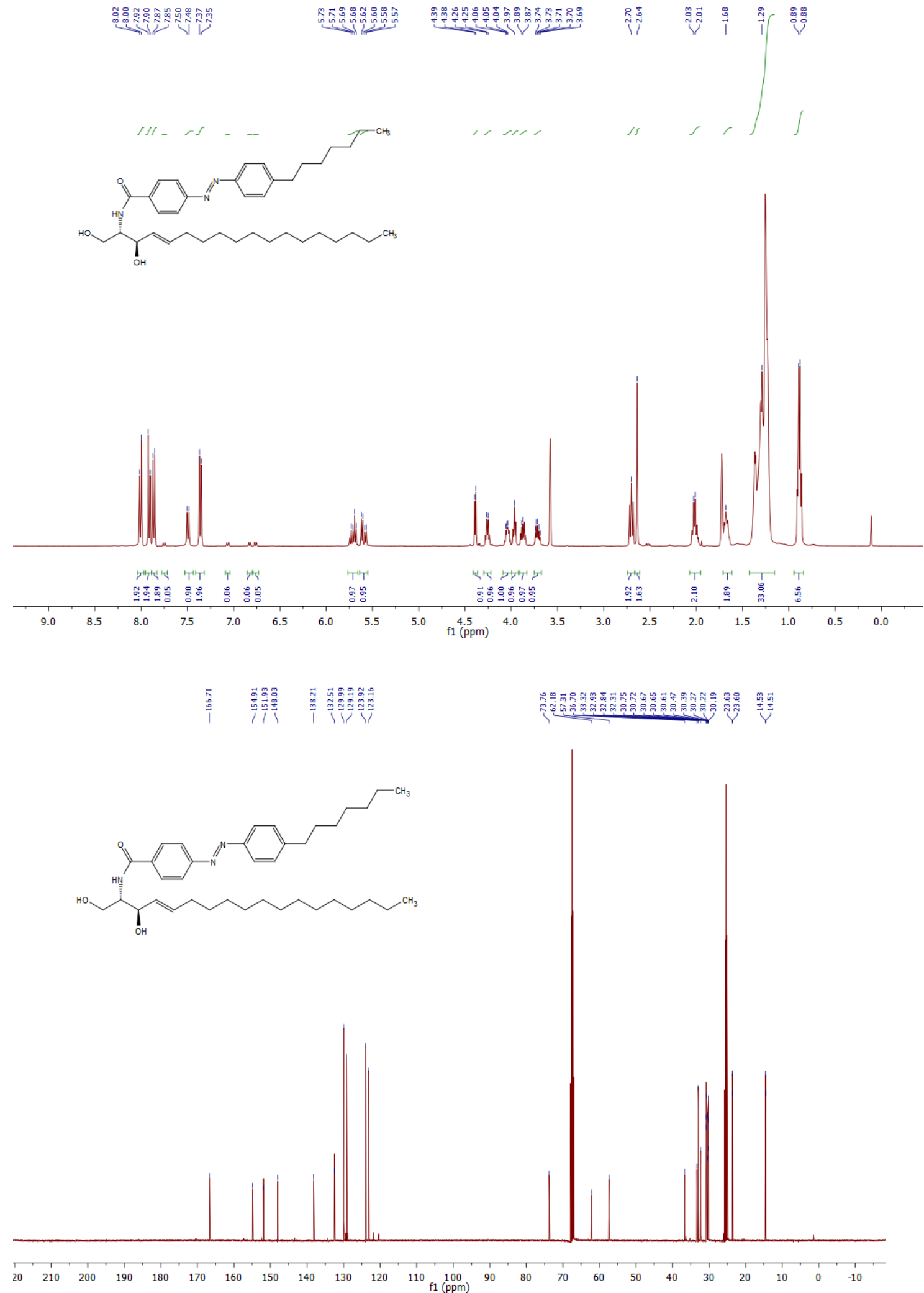
$N$-(7-(4-(p-Tolyldiazenyl)phenyl)heptanamide)-(2S,3R)-2-aminooctadec-4-ene-1,3-diol (ACe-3)

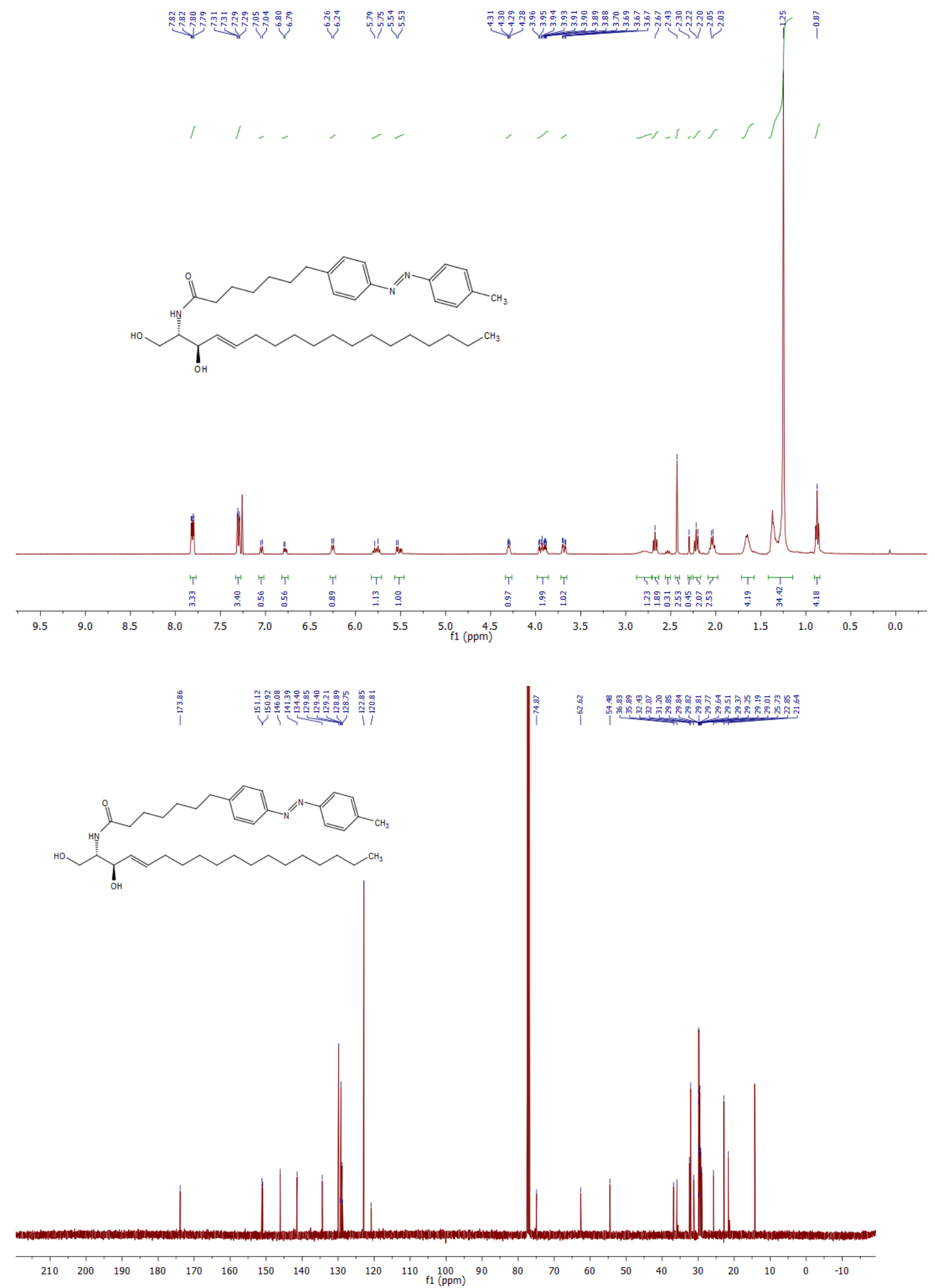




\section{References}

(1) Chiantia, S.; Kahya, N.; Ries, J.; Schwille, P. Biophys. J. 2006, 90, 4500.

(2) Frank, J. A.; Moroni, M.; Moshourab, R.; Sumser, M.; Lewin, G. R.; Trauner, D. Nat. Commun. 2015, 6, 7118. 